\title{
Belgeo
}

Revue belge de géographie

$4 \mid 2001$

Miscellaneous

\section{The geographical structure of capitalism at the origin of cultural protest against globalization as expressed in contemporary politics of identity}

De geografische structuur van het kapitalisme aan de oorsprong van het cultureel protest tegen mondialisering uitgedrukt in hedendaagse vormen van identiteitspolitiek

Pieter Saey, Marleen Renders and Siegfried Thijs

\section{OpenEdition}

\section{Electronic version}

URL: https://journals.openedition.org/belgeo/15642

DOI: 10.4000/belgeo. 15642

ISSN: 2294-9135

Publisher:

National Committee of Geography of Belgium, Société Royale Belge de Géographie

\section{Printed version}

Date of publication: 30 December 2001

Number of pages: $297-314$

ISSN: 1377-2368

\section{Electronic reference}

Pieter Saey, Marleen Renders and Siegfried Thijs, "The geographical structure of capitalism at the origin of cultural protest against globalization as expressed in contemporary politics of identity", Belgeo [Online], 4 | 2001, Online since 31 December 2001, connection on 15 November 2021. URL: http://journals.openedition.org/belgeo/15642 ; DOI: https://doi.org/10.4000/belgeo.15642

This text was automatically generated on 15 November 2021.

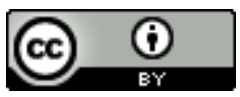

Belgeo est mis à disposition selon les termes de la licence Creative Commons Attribution 4.0 International. 


\title{
The geographical structure of capitalism at the origin of cultural protest against globalization as expressed in contemporary politics of identity
}

\author{
De geografische structuur van het kapitalisme aan de oorsprong van het \\ cultureel protest tegen mondialisering uitgedrukt in hedendaagse vormen van \\ identiteitspolitiek
}

Pieter Saey, Marleen Renders and Siegfried Thijs

Fundamental changes are taking place in the balance of power between political parties or movements in a large number of countries. In nearly all cases, the nature of political discourse underlying national politics has changed radically. The pressure of global economic processes and the collapse of the communist system narrowed the range of arguments around Left-Right issues and thereby created an ideological vacuum in which (at first sight) new kinds of politics could develop: a personalized politics of style (in several European countries) or shifting coalitions of interest groups without any clear ideological thread (e.g. India) on the one hand, and a politics of identity on the other hand (politics of religion, language, regional nationalism, ethnicity) (Cable, 1999, pp. 43-44; see also Amin, 2000; Doom et al., 2000). In order to explain this shift in the political debate, it is tempting to shift focus from conflicts of interest to values and culture accordingly. We wish to resist this temptation. In our opinion, the abovementioned fundamental changes should be explained by the failure of capitalism to bring about universal prosperity. We argue that contemporary changes in the functions of national politics originate from the way contemporary capitalism functions geographically. Just as the development of capitalism has generated conflicting collective interests in the past, so its present failure to secure decent standards of living for unskilled workers in the core states of Western Europe, in addition to its 
failure to secure opportunities for social mobility for the middle strata in the (semi)peripheral states, generates collective interests that clash with existing positions of power. This is the core of our position in the scientific debate, which will be clarified in the course of this article.

2 The reference to the past implies that whenever politics of identity are pursued, they should be analysed in the light of the way capitalism functions geographically, but the article itself is limited to contemporary politics of identity. The reference to a distinction between core states and (semi)peripheral states implies that we shall deal with only one kind of politics of identity, viz. where identity has the connotation of civilization. Following Huntington (1996), we may define civilization as the largest entity, apart from humankind itself, with which an individual can identify him/herself, but we are fully aware that it is a discursive category rather than a real entity:

3 A civilization refers to a contemporary claim about the past in terms of its use in the present to justify heritage, separateness, rights. Chinese civilization, Western civilization, Indian civilization are such contemporary claims. These claims do not have to be based exclusively on verifiable empirical data. These claims are in any case based on contemporary choices about historical boundaries of inclusion. ... The reasons for such claims cannot be located in what happened in the past but in what is happening in the present (Wallerstein, 1991, pp. 235-236).

4 The use of the terms "core state" and "(semi)peripheral state" indicates that we shall rely on Wallerstein's world-systems analysis to define the geographical structure of capitalism. The reason for choosing this approach will be explained in the first section.

We shall justify our position by analysing three cases of politics of identity that have the connotation of civilization: Islamism (Muslim civilization), Hindu nationalism (Hinduism) and extreme right-wing nationalism in Europe (Western civilization). Islamism is a political movement that seeks to confirm the relevance of the Islamic faith, albeit according to a selective and arbitrary interpretation, to political and social issues. It comprises antimodernist factions as well as factions trying to islamitize modernity, and has gathered enormous momentum in North Africa and the Middle East (Renders, 1999). Hindu nationalism and extreme right-wing nationalism in Europe are forms of ethnic nationalism ${ }^{1}$. We shall study them by means of the analysis of two paradigmatic parties, the Bharatiya Janata Party (Indian People's Party) and the Vlaams Blok (Flemish Bloc). The Bharatiya Janata Party is a nationalist party, rallying Hindu discontent with the government's enthusiasm for market disciplines and at the same time finding support for its anti-Muslim populism (Banks and Muller, 1998, p. 415). "It seeks to overcome the heterogeneity and caste divisiveness of Indian society by consolidating a sense of Hindu nationalism around symbols common to all who claim to be Hindus" (Brass, 1995, p. 89) and has acceded to power via elections. The Vlaams Blok is an extreme right-wing populist party, capitalizing on an upsurge in anti(Muslim)immigrant sentiment. Its increasing electoral success is illustrated by the fact that it has won the plurality in Antwerp, the largest city of Flanders. As regards Islamism, no paradigmatic party can be singled out because of the widely divergent situations in the states where the movement is active. Therefore, we will deal with Islamism in general. The discussion of the three cases is the subject of the second section (extreme rightwing nationalism in Europe/Vlaams Blok) and of the third section (Hindu nationalism/ Bharatiya Janata Party and Islamism). In the fourth section, we combine the results of 
the discussion of the three cases and link them to the geographical structure of capitalism as defined in the first section.

The object of the article is to give an answer to the question of how the geographical structure of capitalism can be said to be at the origin of the rise of a particular kind of political movement/party. Two propositions are integral to this answer: (i) an approach starting from conflicts of interests (generated by the geographical functioning of capitalism) leads to different conclusions about the rise of new parties from an approach starting from values and culture, even when both approaches rely on the theory of cleavages to explain the general structure of systems of political parties; (ii) the widespread interpretation of (seemingly) anti-secular politics of identity as being retrograde phenomena is disputable, even when this interpretation derives from an approach starting from conflicts of interests generated by the unequal development of capitalism. The analysis of the Vlaams blok focuses on the first proposition, and the analysis of the Bharatiya Janata Party and Islamism on the second.

7 To sum up, the purpose of the article is to find a causal connection between cultural protest against contemporary globalization in certain forms of politics of identity, and unequal economic development on a global scale. It rejects explanations of this political protest in terms of values and culture and in terms of traditional historical materialism.

\section{The geographical structure of capitalism}

8 World-systems analysis starts from the premiss that the division of labour refers to processes within an already constituted social arena (Hopkins and Wallerstein 1977, p. 114). When local and regional economies are orientated towards production for a market on a supra-regional scale and specialize serving this market, they are constituent parts of a world-economy, whose spatial scope is coextensive with the division of labour among them. This world-economy is the arena in which social action takes place and social change occurs:

[T]o understand the internal class contradictions and political struggles of a particular state, we must first situate it in the world-economy. We can then understand the ways in which various political and cultural thrusts may be efforts to alter or preserve a position in the world-economy which is to the advantage or disadvantage of particular groups within a particular state (Wallerstein, 1975, p. 16).

10 To situate a state in the world-economy amounts to positioning it in the ever-present division of cores, peripheries and semiperipheries, united and reproduced through processes of capital accumulation and unequal exchange. Such an approach matches the meaning of geographical structure or geographical functioning of capitalism in this article, viz. the way in which capitalism generates spatial inequalities on the scale of the discursive category of civilization.

11 The capitalist world-economy (or modern world-system) does not first exist and then develop. Its development is its existence. This development entails the transformation of land, labour and natural resources from phenomena utilized and distributed according to social conventions of limited flexibility into commodities available for purchase on a market. Consequently, the world-economy-historical or actually existing capitalism-is not defined by alienable land or wage labour, but by the structural 
pressures to alienate more land and to proletarize more labour. This implies that "at all points of its historical existence, the combination of allodial and non-allodial forms of tenure, of "free" and "coerced" (or "non-free") direct producers has been central to the functioning of the system" (Hopkins and Wallerstein, 1977, p. 126). Free farmers and wage labour are concentrated in what become core areas; coerced labour and other forms of cheap labour (semi-proletarized labour, unorganized wage labour) are concentrated in what become peripheral areas.

12 Capital constantly tries to tap cheap labour reserves in view of the high profits that keep accumulation going. In the core areas themselves, it first attracted labourers from the countryside, and later guest-workers. In a third phase, it relocated production to the periphery. The fact is that wage labourers get organized and press for higher wages, especially when conditions make it no longer possible to supplement wage income by, for example, subsistence farming. However, higher wages create purchasing power, increasing sales potentials. Capital therefore can meet the wage claims to a degree that maximally corresponds to the increase in productivity. As a result, hightech production and highly skilled and highly remunerated labour tend to concentrate in certain areas. The presence of cheap labour in other areas creates the possibility of low-cost production for the markets of the first areas, and capital can make a choice between relocation and innovation. In this way, capital accumulation leads to a division between peripheral areas or heteronomous cheap labour regions, and core areas or loci of autonomous technological development. At the same time, the need for cheap labour sets structural limits to proletarization.

13 The segregation of high-tech and low-tech production reproduces the former division of labour in which peripheral areas played the role of suppliers of raw materials and of certain foodstuffs (as many peripheral areas still do). This division of labour characterized the world-economy in the long sixteenth century (the period of its emergence), in the subsequent age of mercantilism (the period of its consolidation) and from the mid-eighteenth until the last quarter of the twentieth century. In the first two periods, it was limited to Europe (minus Norway, Russia and the Balkans) and the European colonies in America (minus Louisiana). At the end of the first period, core areas were Holland, Zeeland, south-east England and north-west France. Europe to the east of the Elbe, Northern Europe, Sicily, Sardinia, the southern parts of the Italian and Iberian peninsulas, Ireland, Scotland, Wales and the colonies in America constituted the periphery. European Russia, the Indian subcontinent, the Ottoman Empire and Upper Guinea were incorporated between 1750 and 1850/1880, and the rest of the world in the next half century. The incorporation involves, among other things, the creation of larger units of decision making either at the site of direct production or at the site of mercantile collection of production, the curbing or, as the case may be, destruction of the manufacturing industry, and also changes in the state machinery or political institutions (Wallerstein, 1974, 1980, 1989). It should be noted that "not all the areas physically located inside the boundaries of the world-economy had necessarily been from the outset involved in the social economy". The areas inside the perimeter of the world-economy, yet not belonging to it, are subject to similar processes of incorporation (Hopkins and Wallerstein, 1977, p. 125).

14 A system of division of labour between core areas and peripheral areas in the above sense could not endure without an asymmetrical inter-state system of strong states preventing weak states from breaking that system. The emergence of the world- 
economy in the sixteenth century brought the then political entities into increasingly sustained relations with one another:

The progressive formation of these polities as stronger and weaker states in relation to one another in the emerging European (later, international) state system went hand in hand with the cyclical evolving division of labour between the increasingly "core" areas of the world-system and the increasingly "peripheral" areas. And the worldeconomy became basically structured as an increasingly interrelated system of strong "core" and weak "peripheral" states, in which inter-state relations - and hence patterns of state-formation and, in that setting, the formation of nationally-organized "societies" - are continually shaped and in turn continually shape the deepening and expanding world-scale division and integration of production (Hopkins and Wallerstein, 1977, pp. 112-113).

The coherence of the system depends on a powerful doctrine, the doctrine of universalism, according to which every country has the opportunity to become a modern, highly developed state, if it accepts Western economic and political systems. However, the geographical structure of the system itself makes the fulfilment of universalism impossible. By "geographical structure" we mean (i) the economicgeographical division of core areas (the loci of autonomous technological development, where skilled wage labour possessing considerable purchasing power is concentrated), peripheral or heteronomous areas (where unskilled cheap labour is concentrated) and semiperipheral areas (which consist of declining former core areas and ascending former peripheral areas); and (ii) the political-geographical division in strong and weak states that corresponds with the economic-geographical division.

\section{Extreme right-wing nationalism in Europe: the case of the Vlaams blok}

The Vlaams blok (VB) came into existence as an alliance of two small parties that recruited members from the radical wing of the Volksunie (People's Union, a democratic sub-state nationalist party) and united a year later in 1979. It started to show success only after its transformation from an authoritarian radical nationalist party to an authoritarian populist anti-migrant party (Table 1). Its motto "eigen volk eerst" ("[one's] own people first") is shorthand for insistence on a direct relationship between people and government, putting the will of the people-identified with morality and justice-above all other social standards and mechanisms, and for ethnic hostility, resulting from a belief in the virtue of one's own people and from the idea of a manipulation of this people by dominant or allegedly privileged groups ${ }^{2}$. It takes a virulent anti-socialist and anti-unionist stand in socio-economic matters and displays a visceral hatred of Agalev (Live Differently, the green party of Flanders). 
Table 1. Belgium, House of Representatives; Flemish Region, Flemish Council (\% of seats).*

$\begin{array}{lllll}1950 & 1974 & 1987 & 1995 & 1999\end{array}$

\begin{tabular}{lccccc}
\hline Belgium & & & & & \\
Christian-Democratic parties & $\mathbf{5 1}$ & $\mathbf{3 4}$ & $\mathbf{2 9}$ & $\mathbf{2 7}$ & $\mathbf{2 1}$ \\
social-democratic parties & $\mathbf{3 6}$ & $\mathbf{2 8}$ & $\mathbf{3 4}$ & $\mathbf{2 7}$ & $\mathbf{2 2}$ \\
liberal parties & 9 & $\mathbf{1 4}$ & $\underline{\mathbf{2 3}}$ & $26^{* *}$ & $27^{* *}$ \\
Communistische Partij & 4 & 2 & 0 & 0 & 0 \\
Volksunie & - & 10 & $\mathbf{8}$ & 3 & 5 \\
green parties & - & - & 4 & 7 & $\mathbf{1 3}$ \\
Vlaams Blok & - & - & 1 & 7 & 10 \\
& & & & & \\
\hline
\end{tabular}

Flemish Region

$\begin{array}{lcc}\text { Christelijke Volkspartij } & \mathbf{3 0} & 24 \\ \text { Socialistische Partij } & \mathbf{2 1} & \mathbf{1 6} \\ \text { Vlaamse Liberalen en Democraten } & 22 & \mathbf{2 2} \\ \text { Volksunie } & 7 & 10 \\ \text { Agalev } & 6 & 10 \\ \text { Vlaams Blok } & 14 & 18\end{array}$

* BOLD TYPE: gOVERNMENT PARTY; ITALIC TYPE: gOVERNMENT PARTY IN 1988; UNDERLINED: GOVERNMENT PARTY RESIgNED IN 1988;

-: NOT YET FOUNDED

** Includes: Front Démocratique des Francophones (Democratic Front of French-Speakers), 10\% in $1974,1 \%$ in 1987

Sources: Spectrum Jaarboek, 2000; Witte et al., 1997

According to the analysis of voting behaviour at the general elections of 1995 by Elchardus and Pelleriaux (1998), VB appears to attract unskilled voters who have lost their confidence in humankind and politics. These voters are driven by self-interest, and are ethnocentric and materialistic. According to Elchardus and Pelleriaux, voting behaviour in Flanders is increasingly determined by the perception of a development from a class society to an incompletely meritocratic society. From distrust of this meritocracy, a large part of the unskilled population pleads for authoritarianism. The highly-educated population, on the other hand, has more faith in the individual's capacity and therefore also in democracy. In this way, Elchardus and Pelleriaux are able to explain not only the success of VB but also the success of Agalev. VB and Agalev both relate to a variant of the socio-cultural cleavage, namely distrust of, as opposed to confidence in, the meritocratic society. The socio-cultural cleavage revolves around the issue of living together. Elchardus and Pelleriaux call the cleavage that pits $V B$ and Agalev against each other the new specification of this socio-cultural cleavage. The old specifications, equally revolving around the issue of living together, were religion and nation. They are still polarizing voting behaviour: church-going voters are significantly over-represented in the Christelijke Volkspartij (Christian People's Party, the Christian Democratic party of Flanders) as are Flemish nationalist voters in the Volksunie. Likewise, the socio-economic cleavage, revolving around the issue of equality and 
distribution, pits the Vlaamse Liberalen en Democraten (Flemish Liberals and Democrats) and the Socialistische Partij (Socialist Party) against each other.

Elchardus and Pelleriaux seem to have proven the lasting relevance of the theory of cleavages. This theory states that societal conflicts are neutralized by the existence of political parties organized around fundamental cleavages ${ }^{3}$. In Western Europe, these fundamental cleavages were brought about by two revolutions: the industrial revolution and the political revolution of building a centralized secular national state on the principle of popular sovereignty. The industrial revolution is at the origin of two basic conflicts: capital versus labour (cf. the socio-economic cleavage in Elchardus and Pelleriaux), and agriculture versus industry, or rural versus urban. The political revolution is equally at the origin of two basic conflicts: church versus secular state, and region versus central state, or periphery versus centre (cf. the two old specifications of the socio-cultural cleavage in Elchardus and Pelleriaux). In their turn, the basic conflicts are at the origin of (families of) political parties. However, Elchardus and Pelleriaux state the theory in terms of conflicting values. An explanation of the rise of political parties on the basis of such conflicting values can be very deceiving, because it confines itself to subjective reactions to objective processes, leaving the latter out of the picture. If we adhere to the theory but start from conflicting interests, we arrive at another explanation of the rise of VB and Agalev.

In Western Europe, the substitution of an industrial class society for the agrarian estate society affected the position of power of certain social groups and organizations and brought other social groups and organizations into comparable positions of power. These groups and organizations were able to transform their sectional interest into a collective interest by means of an ideology that appeared to exert an attraction on members of all other social strata. As a consequence, they constituted what may be called a natural electorate for political parties organized to promote such collective interests. In the course of time-through objective processes-a party may lose (a part of) its natural electorate and voters because of (i) the development of new cleavages, calling new parties with an overlapping natural electorate into existence, (ii) the declining importance of the cleavage from which it derives its raison d'être, or (iii) the neglect of its raison d'être. A party may also decline when its natural electorate simply decreases (the fate of socialist parties to the degree that their natural electorate consists of manual labourers). Following this line of thought, we reach the conclusion that Agalev and VB are organized around two different cleavages, instead of a single one as Elchardus and Pelleriaux contend.

21 Agalev derives its right to exist from a new cleavage, namely the political polarization around the issue of the economic power of decision brought about by the conflict between environment and economic growth. The realization of ecologist standpoints implies indeed an unprecedented curtailment-by the community-of the exercise of the right of ownership by private enterprises. VB represents an extreme right-wing populist nationalism that gains increasing acceptance with (until now) leftist milieux like trade unions. We suggest three factors that may account for its attraction and that are of paradigmatic value for the explanation of the recent rise of extreme right-wing nationalism in Europe:

(i) As a form of ethnic-linguistic nationalism, it fills the emotional vacuum created by the continual substitution of former morals and customs by new ones (the defining 
feature of modernity), which is intensified in times of insecurity due to unemployment, flexibility carried to extremes, and ageing ${ }^{4}$.

(ii) As a form of extreme right-wing populism, it pretends to offer an alternative to the increasing centrism of the democratic parties, which seem to neglect their raison d'être, thereby contributing to a crisis of legitimacy. Mass media, strikers and marchers increasingly denounce the excrescences and shortcomings of what we are inclined to call Belgian particracy ${ }^{5}$ (malfunctioning of government institutions, outstanding weighty judicial dossiers, malversation, dubious funding of political parties, institutional fatness, powerlessness against shutdowns). Centrism means that a party aims at becoming a people's party, i.e. a party that tries to promote the sectional interests of all social strata (as the Christelijke Volkspartij did from the beginning) ${ }^{6}$. It also means that leftist parties no longer put forward the demands of economic democracy and social reform. As such, centrism boils down to the capitulation, before the processes of internationalization of production and investment, of a political class that has fallen under the spell of the ideology of neoliberalism. In the same vein, Meynen (1997) argues that the rise of the extreme right (a) was prepared by the ideological restoration in the 1980s (the break-through of neoliberalism) and (b) was made possible by what he calls postreformism and the adaptation of the labour movement to this postreformism.

(iii) As a form of anti-migrant populism, it complies with the demands of those who want to discriminate against people of foreign origin because the latter profit from the welfare state, which is based on a social pact concluded by the nationally organized employers and the nationally organized labour movement without any intervention from, or contribution by, foreigners (Deslé, 1992).

In this way, $V B$ is able to attract people who are emotionally vulnerable, opt for authoritarian policies, and feel deprived. It reflects a new cleavage, national (or European) community versus global (or cosmopolitan) community, involving a polarization around the issue of an inclusive versus exclusive society. Unskilled workers, who experience exclusion and direct competition with the low-wage countries as well as with the so-called migrant workers, have an interest in the conservative authoritarian answer to this cleavage (closing the borders instead of welcoming migrants).

\section{Hindu nationalism and Islamism}

\section{Politics of identity in the decolonized world}

Cleavages in decolonized states are related to the struggle of liberation. In this respect, Ireland is a decolonized state: Fianna Fáil (Soldiers of Destiny) and Fine Gael (Family of the Irish) still hold 131 of the 166 seats in the House of Representatives (Spectrum Jaarboek, 2000). They came into existence as political factions of the liberation movement by splitting off from Sinn Féin (Ourselves Alone), the radical wing of the movement (nowadays marginalized). However, whereas in Ireland the party system has hardly changed since independence, in most of the decolonized states the party system (often after an intervening period of one-party system) has become more complicated. "The claim to one's own mode of existence as a superior value and a political right" seems to account for one of the new cleavages that may explain the rise of new parties 
in the decolonized world. The cleavage that polarizes political parties around issues like religion or ethnicity may be interpreted in terms of values, whereby movements like Islamism and Hinduism are taken to be primordial forces. Such an interpretation amounts to a culturalist interpretation of geopolitics, of which a trend-setting example has been Huntington, 1993a, 1993b, 1996. Actually there are two culturalist interpretations, a strong one and a weak one, Huntington being an example of the former, and Sahlins (1994) of the latter. The strong culturalist interpretation refers to the internal dynamics of a cultural order: the rise and success of a cultural movement is the progressive realization of an ideal, as if, on the breeding ground of a particular national character, a small germ, initially overrun by a Westernized state structure, has grown into a fully developed tree. The weak culturalist interpretation refers to the interaction between a cultural order and exogenous factors: a cultural order strengthens itself by making certain elements of Western culture instrumental to its own functioning. Only strong culturalism holds an undiluted primordialist view of culture and ethnicity. Weak culturalism is much more sophisticated ${ }^{8}$. An interpretation in terms of interests, on the other hand, refers to the dependence of a cultural movement on politico-economic developments. In the next sections, we present evidence in favour of this second interpretation. In one and the same breath we cast doubt on the view that these movements are retrograde phenomena, including the variant of historical materialist origin of which Amin, 2000, is an authoritative exponent: "In Latin America, sub-Saharan Africa and the Arab world, the developmental nationalism of the Bandung years is a matter of the past. The retreat has not provided a way of moving beyond these policies. On the contrary, it has resulted in serious regression. I have suggested that we should interpret the ethnic assault on the nation (here as in Eastern Europe and the former USSR), and the illusions of religious fundamentalism (principally Islamic, but also Hindu) as manifestations of this regression. [...] these involutions raise the possibility of a kind of neo-fascism of weak countries" (Amin, 2000, p. 101).

\section{Hindu nationalism: the case of the Bharatiya Janata Party}

The Bharatiya Janata Party (BJP), founded in 1980, is part of a larger family of organizations working towards the promotion of Hindu nationalism. This family of organizations is known as the Sangh Parivar. The ideological and organizational backbone of the structure is the Rashtriya Swayamsevak Sangh (RSS, the National Volunteers Organization). Apart from the BJP as a political party, the movement includes a whole array of other organizations such as student organizations, a religious foundation and a labour union. Under the aegis of RSS, the Hindu nationalists built temples, provided health care and education, and conducted many political activities in order to make the population receptive to its ideal: a multi-faceted unity amongst all Hindus (Andersen and Damle, 1987; Jaffrelot, 1996). The political success of Hindu nationalism is reflected in its electoral strength: the BJP is currently the largest party of India and is part of the governing Democratic Alliance (Table 2). It is the successor of the Jana Sangh, which was founded by a dissident member of the Congress Party and RSS activists in 1950. In 1980 the bulk of the Jana Sangh formed the BJP as a reaction to the efforts by the leadership of Janata, a multiparty coalition that had acceded to power after 30 years of uninterrupted Congress government, to ban party officeholders from participation in the activities of the RSS ${ }^{9}$. 
Table 2. India, House of the People (number of seats).*

\begin{tabular}{|c|c|c|c|c|c|c|}
\hline & 1984 & 1989 & 1991 & 1996 & 1998 & 1999 \\
\hline Bharatiya Janata Party & 2 & 88 & 119 & $\underline{161}$ & 179 & 182 \\
\hline (Democratic alliance & & & & $\underline{194}$ & 252 & 296) \\
\hline \multicolumn{7}{|l|}{ Indian National } \\
\hline Congress - Indira & 401 & 207 & 225 & 140 & 141 & 115 \\
\hline \multicolumn{7}{|l|}{ National Front } \\
\hline United Front (National Front/Leftist Front) & - & $* *$ & 144 & 55 & 179 & 97 \\
\hline Communist Party of India - Marxist & 22 & 32 & 35 & $* * *$ & *** & 33 \\
\hline
\end{tabular}

* BOLD TYPE: gOVERNMENT PARTY; UNDERLINED: gOVERNMENT PARTY, RESIgNED AFTER 13 DAYS;

- : NOT YET FOUNDED

** Telegu Desam (Telegu Nation): 28 seats; Janata (People's Front): 10 seats

$\star \star \star 32$ seats in 1996 and 1998, included in the number of seats of the United Front

SOURCES: BANKS AND MULLER, 1998; SPECTRUM JAARBOEK, 1988, 1990, 1992, 1997, 1999, 2000 upper castes in the cities. As the movement grew, it became increasingly popular with the lower castes too. The RSS disregarded the "traditional" caste system, as consolidated by the British in their colonial administration. It promoted its activities among the entire Hindu community without taking into account to which caste any individual Hindu belonged. Participating in RSS activities thus allowed members of the lower castes to improve their social status. Membership in the RSS liberated them from the social immobility induced by the caste system. The Hindu Rashtra, the united Hindu Nation, was to take precedence over traditional forms of social organization. After India's independence, the RSS attracted its membership from social strata that belong to the varnas of the Brahmans and the Vaisyas, such as bureaucrats, professionals, small traders, merchants and shopkeepers, who are opposed to the policy of the governing Congress Party. They feel that the party, which had been at the forefront of the independence struggle and identified itself with the effort of building the modern Indian state, was no longer able to preserve the political and social unity of that state (Bose, 1997). Neither did the Congress Party succeed in its stated aims of economic development and social equality. Indira Gandhi's communalist rhetoric, which tended to turn each conflict into a conflict between ethnic or religious communities, contributed to the legitimation of Hindu nationalist politics (Bose, 1997, pp. 123-124; Jaffrelot, 1996, p. 336). The problems were exacerbated and accentuated by the embroilments around the government's positive action policies, which allocated seats in the legislative bodies, jobs in the civil service and access to higher education to members of disadvantaged population groups (Bose, 1997, p. 142). This contributed directly to the electoral breakthrough of the BJP in 1989 and its consolidation in 1991, as the embroilments led members of the upper castes to vote for the BJP. In principle, reservations policies are nothing more than the implementation of certain articles of 
the constitution that make it possible to allocate civil service jobs, seats in the legislative bodies and access to higher education to members of the Scheduled Castes (in principle coinciding with the untouchables), the scheduled Tribes and any backward class of citizens (later designated as Other Backward Classes, in principle to be defined according to economic criteria). However, when the younger generations of the $\mathrm{OBC}$ started to agitate for an extension of the positive actions, and in 1980 the Mandal Commission recommended the extension of positive actions in favour of the $\mathrm{OBC}$ to the level of the national state, the upper castes felt that the social status quo was threatened, although afterwards the Congress government appeared to neglect the recommendations of the Mandal Commission (Bose 1997). Ten years later, the BJP accused the National Front government of accentuating the caste conflicts, when the latter included the conclusions of the Mandal Commission in the political agenda. The BJP leader began a religious pilgrimage to Ayodha to enhance the unity of all Hindus. He was detained and the BJP terminated its support to the government. The BJP became even more successful in the late 1990s by at first canalizing Hindu discontent with the government's market orientated social and economic policy and later moderating its Hindu nationalist image to forge ties with state and regional parties (Banks and Muller, 1998, p. 415).

31 The BJP's goals are similar to those of the Congress Party. It wants to transform India into a modern, industrial, military power with a united nation and a disciplined work force (Brass, 1995, p. 88). Yet, in contrast to the Congress Party, it makes frequent use of Hindu beliefs and symbols as a focus for creating a true national identity. One of the important aspects of the political discourse of the BJP is the notion of integral humanism, the justification of which is found in the Vedas. Integral humanism rejects Western political philosophy (capitalism and socialism alike) because of its materialism. It propagates social harmony and popular participation in political and economic matters (Andersen and Damle, 1987, pp. 172-174). Other points of reference are positive secularism and Gandhian socialism (Jaffrelot, 1996, p. 316). Through positive secularism, the BJP attacks the "pseudo-secularism" of the Congress Party. The Congress Party is accused of favouring the Muslim minority over the Hindu majority by allowing them in certain special cases to live according to their own religious laws (as opposed to Indian national law) (Bose, 1997, pp. 128-129; Van der Veer, 1994, p 103). Through the propagation of concepts like Gandhian socialism, the BJP makes ample use of Mahatma Gandhi's symbolic capital and tries to associate the party with his heritage.

The BJP can be qualified as an Indian variant of a people's party, weaving between plain RSS populism and moderated Hindu nationalism, and trying to attenuate its upper caste image by admitting members of the $\mathrm{OBC}$ to the party apparatus. The implication is that the BJP is not a fundamentalist religious party ${ }^{10}$, if we want to use this epithet correctly. Fundamentalism as an organized movement dates from the early twentieth century. It consisted of ultraconservative Protestants who vigorously opposed the new historical and literary approach of the Bible. They only permitted a literal interpretation of the Scriptures, the Word of God, the sole standard in religious matters as well as in political and social issues. By extension, fundamentalism means the idea that every revival or criticism should be based on an absolute return to what is written in the holy texts, and the one and only reason for this return is the (lost) purity and virtuousness of the past. This does not apply to the BJP. Neither does it apply to Islamism, as the next section will show. 


\section{Islamism}

Public life in much of the Muslim world in recent decades has been marked by an increase in the importance and visibility of Islamic symbols, practice and discourse. This is notably the case in the Middle East and North Africa. The phenomenon is widespread; yet the internal diversity in appearance and purpose is striking. The reIslamization of public life cannot be considered as a mere upsurge of religious fervour among the Islamic peoples, neither is it the emergence of a universal/essential Islamic identity. The phenomenon coincides with a decrease in the legitimacy and credibility of movements and parties inspired by "old" ideologies such as communism (or socialism for that matter) and secular nationalism. Governments born out of the nationalist struggle of the 1950s and '60s are challenged by different groups, in most cases groups using an identitarian, Islamic discourse. This movement is broadly called Islamism.

The resurgence of Islam has become apparent through a variety of political and societal expressions. Media coverage by Western news agencies (especially since the end of the Cold War) tends to focus on "Islamic" terrorist activities such as kidnappings, bombings or other forms of violent political action. Political action, however, also and more importantly takes place at other levels of public life. Since the 1970s a large Islamic third sector has emerged: Islamic voluntary organizations take up social activities for the benefit of (mainly) urban populations (Tozy, 1996, p. 61; Ayubi, 1996, p. 196). They distribute food and clothes, and organize health care, community care and events such as marriages, which are beyond the financial reach of the average family if they are organized privately. The Islamists also participate in parliamentary politics, when allowed. In Jordan, members of the Muslim Brotherhood have even risen to the rank of Minister of Education and of Religious Affairs. In Algeria, the Islamists won an important majority in the local elections of 1990. Yet all parties referring to religion or ethnicity as their main issue of concern were subsequently banned. This government decision marked the start of years of unrestrained violence in the country. Where banned from formal political participation, the Islamist groups either keep operating illegally, stand as independent candidates, or search for alternatives such as unofficial alliances with secular government-approved parties or more indirect forms of political participation (Rousillon, 1990, p. 28). In Egypt, Islamists have become an important political factor in the professional organizations of lawyers, medical doctors and engineers (Rosefsky-Wickham, 1997, p. 126).

These highly skilled professionals form the ideological backbone of the Islamist movement. It is not the traditional Islamic leaders, the ulama, who are in control, but laymen with a modern education (Khosrokhavar, 1994, p. 129). The Islamists are also very popular with future professionals, attracting huge followings among students at schools and universities. Many of the elected student bodies (notably in Palestine) have an important Islamist representation. In terms of classification according to social class, most of the militants are from a lower-middle-class background. However, upper classes also are attracted to the Islamist message; moreover, it is they who provide the greatest financial leverage within the movement, through their positions in business and banking. The rank-and-file of the movement is made up of people with a lowerclass background, who are increasingly experiencing difficulty in meeting their basic needs (Pfeifer, 1997, p. 162). 

ultimately the state. Yet Islamization is an elusive concept: the different movements and individual militants do not agree about its content. Most avoid internal controversy by merely stating that they want the shari'a, the Muslim law, reintroduced. This does not, however, give any clues as to the content of Islamic law: Islamists agree that the divine revelations of the Qur'an and the Sunnah are the sources for legislation, but are still subject to (judicial) interpretation. The position of Islamist ideology on a scale from left to right is not precisely determinable (Pfeifer, 1997, p. 157). Movements and militants can be conservative or progressive, as far as these categories apply. This is clearly the case looking at, for example, socio-economic issues such as distribution of wealth or more philosophical issues such as the position and status of women in society. Some Islamist movements are convinced that the existence of inequality is the will of God, while others claim that inequality is an injustice created by unjust rulers, which cannot be tolerated by pious Muslims. Some Islamist movements think that women should be totally submissive to their husbands; others insist that Islam bestows certain unalienable rights on women (Burgat, 1996, p. 246).

What all Islamist movements have in common, however, is their oppositional nature. They turn against the secular post-independence regimes and identify this secularism as the root cause of their failure to build a prosperous and just society. Secularism was something the new political regimes inherited from the West. Immediately after independence, the political, secularized elites embarked on a "modernization and development" effort according to the rules taught to them by their former colonial masters. A heavily centralized modern state was built in order to achieve economic development. Governing that state was to be the sole prerogative of the secular elites. In exchange for political peace, the populations were provided with different aspects of welfare such as free medical care, free education and a guaranteed job (Vieille, 1995, p. 315). This social contract came under pressure as the state's financial and political resources failed to meet the demands of the growing and increasingly educated population. Aspiring graduates found that they could be out of work for years; poorer strata of the population were deprived of essential means to sustain themselves. As soon as the costs and benefits of modernization proved to be unequally distributed, movements that challenged the western ideological domination started to emerge.

According to the Islamists, Western modernity has proved not to be the way in which Muslims can be successful. They accuse their governments of merely imitating the West. The West, and by proxy the post-independence regimes and the political elites of which they consist, are dismissed as morally reprehensible. Islamists accuse the political elites of being infidels and therefore illegitimate rulers in a Muslim society. They reject the notions of liberation and emancipation professed by the nationalists, because these proved deceptive: liberation from colonial domination apparently had only meant liberation of the secular elites and not of the entire population (Burgat, 1997, p. 77). For members of the poorer strata of the population, Islamism is a vehicle of protest, a way to challenge the status quo and to attack the political elites that did not live up to their pre-independence promises of liberty and prosperity. However, members of some more prosperous strata also have an interest in the Islamist ideology, because it seeks to diminish the political power of the secular bureaucrat elite and to loosen state control over all aspects (especially economic) of life. 
39 Although Islamism, as opposed to nationalism and socialism, uses religious contexts and discourses to bring its points home, this does not mean that secular aspirations are replaced with religious ones. Islamism is a project for a society aimed at fulfilling the worldly aspirations of its politically and economically deprived adherents. This is translated into a form of cultural protest, at least partly because the economic/political and cultural gaps overlap: the Westernized political elite is pitted against an Islamic counterforce consisting of an aspiring educated elite and the deprived masses who feel betrayed by a nationalist ideology that has not lived up to its promises. Higher classes jump on the bandwagon because they see the advantages of a "smaller" state and economically more liberal policies.

\section{Politics of identity and the geographical structure of capitalism}

40 Hindu nationalism and Islamism oppose the development policies of the governing powers for obvious reasons: the policies are a failure. In most cases, these governing powers, who take universalism for granted, represent secular nationalism. Amin (2000) even speaks of development nationalism. The list of factors that account for the failure of development policies includes undoubtedly the weaknesses of individual state machineries, individual regimes and individual politicians. However, whatever the shortcomings of the governing powers may be, governments that rule weak (semi)peripheral states have to come up against the hard facts of the world-economy. Prosperity is reserved for only a minority of regions. As a rule, (semi)peripheral states have insufficient means to realize a distribution of welfare among the population comparable to that in core states. Welfare can be created only for elites with their clients who nestle in and around the state apparatuses. Once they are in power, they will stick to it at all costs, the more so when it concerns the elite that has gained the independence. Democracy will suffer. Opposition will be misperceived as subversion, and in this way, governing powers will make themselves incapable of preserving the unity of society. Outbreaks of violence and rebellion are proof of the depth of the ensuing crisis of legitimacy.

41 We reach the conclusion - and corroborate thereby the view of Wallerstein (1995) on the political development in the South ${ }^{11}$ - that Islamism and Hindu nationalism are able to recruit members of what may be called the equivalent of the European middle class because it was not possible for the nationalists of the first and second generation to build a modern, thriving state on the periphery of the capitalist system. They are also able to recruit members of the lower social strata because of their assiduous welfare work over many years at the grassroots level, providing essential services where the state has failed to meet its responsibilities.

In a similar way, the rise of extreme right-wing nationalism/populism in Western Europe should be linked to the role that core areas play in global capitalism. Extreme right-wing nationalism is able to recruit unskilled workers because there are not enough jobs for these workers. However, as an authoritarian movement, it is also able to recruit members of other social strata because of the centrism of the democratic parties. Overwhelmed by the need to secure the competitiveness of the national economy, these democratic parties seem to forget why they came into existence, thereby creating a crisis of legitimacy. 

of legitimacy of the regimes concerned, not in the sense that present-day globalization generates new (economical or socio-economical) interests which would be to the advantage of the political parties and movements we dealt with, but in the sense that present-day globalization reproduces the geographical structure of capitalism and thereby prevents the governing powers from promoting certain existing interests in an adequate way. In these circumstances the programmes of populist parties and people's parties which advocate a politics of identity appeal to many people, including the upper social strata which in the case of India benefit, for example, from the maintenance of the status quo in the matter of reservations, and in the Islamic world from a smaller degree of state interference. the division of core and (semi)peripheral areas does not amount to a full explanation of the geography of this politics. Firstly, the content of the ideology behind the politics of identity may make a difference. We ought to be aware of the risk of falling into a sociological determinism by fitting politics of identity to inescapable sociological constraints of the world-system. The content of the ideology does matter. As Chatterjee says in his study on nationalist thought in the colonial world, it is the claims of the ideologists about what is possible in a particular historical context and what is legitimate or morally justified that give specific shape to their politics (Chatterjee, 1993, p. 40). Although we have discussed the ideologies of the three movements/ parties, we have not analysed them from this perspective. Secondly, it goes without saying that the three movements/parties are only successful in certain parts/states of the relevant states/regions and are marginalized or even absent in other parts/states. In the third section we mentioned that Hindu nationalism originated in the Hindispeaking part of India and that the BJP still has its largest following in this part. We also pointed to the divergent position of Islamism in the Arab-speaking countries around the Mediterranean Sea, which is bounded up with the way in which the governing powers try to oppress, confine or incorporate Islamism ${ }^{12}$. With regard to VLAAMS BLOK, certain differences between Flanders and Wallonia which may explain why an extreme right-wing populist party is successful only in the Dutch-speaking part of Belgium readily come to mind: there is the acceptance of more state interference in economic matters in Wallonia; the longer tradition of immigration in Wallonia; the presence, and at certain times the dominance, of authoritarian tendencies in the substate nationalist Flemish Movement. Whether or not these differences count as real causes still needs to be examined.

45 However, this article is not an exercise in electoral geography, and the analysis of this kind of spatial variation is outside our scope. Suffice it to say that such an analysis would require a more comprehensive definition of the geographical functioning of capitalism.

\section{Conclusion}

Undoubtedly, the rise of both Islamism and Hindu nationalism epitomize the claim to one's own mode of existence as a superior value and a political right. However, that does not imply that it should be explained as a cultural struggle against Westernization rather than as a cultural protest against the political-economic wrongs inherent in 
(semi)peripheral capitalism. Likewise, the rise of extreme-right nationalism in Western Europe should be interpreted not as a self-referential cultural phenomenon, but analysed in the light of the role that core states play in global capitalism.

The three cases of politics of identity are related to a crisis of legitimacy. Yet this is not to say that Islamism and Hindu nationalism are the non-Western equivalents of extreme right-wing nationalism in Europe. The rise of extreme right-wing nationalism in Europe is connected with the failure of democratic parties to find an answer to a set of problems, of which a lack of employment and social security for the unskilled population is the most important. This phenomenon is integral to the role that core areas play in the world-system as it functions today. The cleavage involved, national (or European) community versus global (or cosmopolitan) community, raises the issue of an inclusive versus exclusive society. Extreme right-wing nationalism in Europe is on the side of authoritarian exclusive society. The claim to one's own mode of existence as a superior value and a political right in the decolonized world entails the rejection of modernity in its Western form (and in some cases even of modernity in general). This may lead to an exclusive society, but not necessarily to an authoritarian one. The rise of Islamism and Hindu nationalism is connected with the inability of the generation of nationalists that have won independence, and their immediate successors, to build a modern state. This phenomenon is integral to the role that (semi)peripheral areas play in the world-system. The transformation of a modern Western democratic state into an authoritarian closed society is quite a different matter from the construction of a (possibly democratic) non-Western modern state on the basis of principles derived from religious texts or beliefs. To call the latter fundamentalism is a category mistake that is reminiscent of Orientalism ${ }^{13}$.

\section{BIBLIOGRAPHY}

AMIN S. (2000), Capitalism in the age of globalization, London, Zed Books, third impression.

ANDERSEN, DAMLE (1987), The brotherhood in saffron: the Rashtriya Swayamsevak Sangh and Hindu revivalism, Westview Press.

ASHCROFT B., AHLUWALIA P. (1999), Edward Saïd, the paradox of identity, London, Routledge. AYUBI N. (1996), Political Islam, London, Routledge.

BANKS A.S., MULLER T.C. (eds.) (1998), Political Handbook of the World: 1998, Binghamton, CSA Publications.

BOSE S. (1997), "Hindu nationalism and the crisis of the Indian State: a theoretical perspective", in BOSE S., JALAL A. (eds.), Nationalism, democracy and development: state and politics in India, Oxford, Oxford University Press.

BRASS P. (1995), The politics of India since independence, Cambridge, Cambridge University Press, second edition. 
BULLOCK A., STALLYBRASS O. (eds.) (1981), The Fontana dictionary of modern thought, London, Fontana/Collins, 7th impression.

BURGAT F. (1996), L'islamisme en face, Paris, La Découverte.

CABLE V. (1999), Globalization and global governance, London/New York, The Royal Institute of International Affairs.

CHATTERJEE P. (1993), Nationalist thought and the colonial world: a derivative discourse, London, Zed Books, second impression.

DESLÉ E. (1992), “De betekenis van (internationale) arbeidsmigraties en van het racisme voor de ontwikkeling van de (nationale) welvaartsstaat”, in DESLÉ E., MARTENS A. (eds.), Gezichten van hedendaags racisme, Brussel, VUBPress, pp. 219-262.

DEWACHTER W. (1992), Besluitvorming in politiek België, Leuven/Amersfoort, Acco.

DOOM R., GORUS J. (eds.) (2000), Politics of identity and economics of conflict in the Great Lakes Region, Brussel, VUBPRess.

ELCHARDUS M., PELLERIAUX K. (1998), “De polis verdeeld - hoe de kiezers links en rechts herdefiniëren”, in SWYNGEDOUW M., BILLIET J., CARTON A., BAERTEN R. (red.), De (on)redelijke kiezer, Leuven/Amersfoort, Acco, pp. 183-210.

HOBSBAWM E.J. (1994), Nations and nationalism since 1780, Cambridge, Cambridge University Press, reprinted second Canto edition.

HOPKINS T., WALLERSTEIN I. (1977), "Patterns of development of the modern world-system", Review, 1, pp. 111-145.

HUNTINGTON S. (1993a), “The clash of civilizations?”, Foreign Affairs, 75, pp. 22-49.

HUNTINGTON S. (1993b), “If not civilizations, what?”, Foreign Affairs, 75, pp. 186-194.

HUNTINGTON S. (1996), The clash of civilizations and the remaking of world order, New York, Simon \& Schuster.

JAFFRELOT C. (1996), The Hindu nationalist movement and Indian politics 1925 to the 1990s: strategies of identity-building, implantation and mobilization (with special reference to Central India), London, Hurst.

KHOSROKHAVAR F. (1994), "Marginalisation de la jeunesse”, in GRESH A., ADELKHAH F., ARKOUN M., BURGAT F. (eds.), Un péril islamiste, Bruxelles, Com-plexe, pp. 129-147.

LABRIE A. (1992), "La religion civile: nationalisme, nationale staat en modernisering in Europa", in WESSELS L.H.M., BOSCH A., Veranderende grenzen, nationalisme in Europa, 1815-1919, Nijmegen, SUN, pp. 59-103.

LIPSET S., ROKKAN S. (1967), Party systems and voter alignments, New York, The Free Press.

MELCHING W. (1992), "Natie, identiteit en nationalisme”, in BOSCH A., WESSELS L.H.M., Veranderende grenzen, nationalisme in Europa 1919-1989, Nijmegen, SUN, pp. 23-58.

MEYNEN A. (1997), "De economische en sociale politiek sinds de jaren vijftig”, in WITTE et al., pp. 285-354.

PFEIFER K. (1997), “Is there an Islamic economics?”, in BENIN J., STORK J. (eds.), Political Islam, essays from Middle East Report, Berkeley, University of California Press, pp. 154-164.

RENDERS M. (1999), De schaduwkant van de maan. Islamisme in politiek, economie, maatschappij, en het wereld-systeem, Gent, Academia Press.

REYNEBEAU, M. (1995), Het klauwen van de leeuw, Leuven, Van Halewyck. 
ROSEFSKY-WICKHAM C. (1997), “Islamic mobilisation”, in BENIN J., STORK J. (eds.), Political Islam, essays from Middle East Report, Berkeley, UCP, pp. 120-135.

ROUSILLON A. (1990), “Entre al-jihad et al-Rayyan: phénoménologie de l'islamisme égyptien”, Maghreb, Machrek, 127, pp. 17-50.

SAHLINS M. (1994), "Goodbye to tristes tropes: ethnography in the context of modern world history”, in BOROFSKY R. (ed.), Assessing cultural anthropology, New York, McGraw-Hill, pp. 377-394.

SPECTRUM JAARBOEK $(1988,1990,1992,1997,1999,2000)$, Uitgeverij Het Spectrum.

TAYLOR P.J. (1993), Political geography. World-economy, nation-state and locality, Harlow, Longman Scientific \& Technical, third edition.

THIJS S. (1999), Hindoe-nationalisme als antisysteembeweging?, M.A. thesis, University of Ghent.

TOZY M. (1996), “Movements of religious renewal”, in ELLIS S. (ed.), Africa now. People, policies, institutions, The Hague, DGIS, pp. 58-74.

VAN DER VEER P. (1994), Religious nationalism, Hindus and Muslims in India, Berkeley, University of California Press.

VIELLE P. (1995), “L’irrépressable imaginaire”, Peuples Méditerranéens, 70-71, pp. 309-329.

WALLERSTEIN I. (1974), The modern world-system - capitalist agriculture and the origins of the European world-economy in the sixteenth century, New York, Academia Press.

WALLERSTEIN I. (1975), World inequality, Montreal, Black Rose Books.

WALLERSTEIN I. (1980), The modern world-system II - mercantilism and the consolidation of the European world-economy 1600-1750, New York, Academia Press.

WALLERSTEIN I. (1983), Historical capitalism, London, Verso.

WALLERSTEIN I. (1989), The modern world-system III - the second era of great expansion of the capitalist world-economy 1730-1840s, San Diego, Academia Press.

WALLERSTEIN I. (1991), Geopolitics and geoculture, Cambridge, Cambridge University Press.

WALLERSTEIN I. (1995), After liberalism, New York, The New Press.

WITTE E., CRAEYBECKX J., MEYNEN A. (1997), Politieke geschiedenis van België van 1830 tot heden, VUBPress/Standaard Uitgeverij, $6^{\text {de }}$ herziene uitgave.

ZEMNI S. (1999), "Gewelddadig islamisme in transitie: over jihad en business", Vlaams Marxistisch Tijdschrift, 33, pp. 70-77.

\section{NOTES}

1. On ethnic(-linguistic) nationalism, see Hobsbawm, 1994.

2. Cf. the definition of populism in Bullock and Stallybrass, 1981.

3. As we interpret it. For the original theory of cleavages, see Lipset and Rokkan, 1967.

4. On nationalism as a means of defence against modernity or modernization, see Reynebeau, 1995, p. 33, and also Labrie, 1992 and Melching, 1992, who both refer to Hobsbawm's notion of "invention of tradition".

5. Cf. Dewachter, 1992, who convincingly argues that particracy is the appropriate designation of decision-making in political Belgium. 
6. A people's party is the intermediate stage in the movement towards a representation party (a party that makes direct concerted appeals to the electorate beyond narrow party channels but is not primarily concerned with mobilizing voters to accept a special political cause; it is pragmatic and eschews ideology. In the age of new mass communications, political leaders can appeal to the electorate directly, and we enter the world of personalized politics of style: see Taylor, 1993, pp. 256-257).

7. This phrase is borrowed from Sahlins, 1994.

8. Huntington (1996) first reifies civilizations and then rejects their mixing. He presents a number of examples (Turkey, Mexico, Russia, Australia) to show that mixing of civilizations inevitably leads to cultural schizophrenia. As a result there is a sharp contrast between his warning for, and vision of, a clash of civilizations and the following quotation from Sahlins' defence of culturalism: "... how else can the people respond to what has been inflicted on them except by devising on their own heritage, acting according to their own categories, logics, understandings? I say "devising" because the response may be totally improvised, something never seen or imagined before, not just a knee-jerk repitition of ancient custom. "Tradition" here functions as a yardstick by which the people measure the acceptability of change ... Cultural continuity thus appears in and as the mode of cultural change. The innovations follow logically though not spontaneously, and in that sense not necessarily - from the people's own principles of existence ... Rather than the overthrow of the world system, which is now an irreversible fact of their existence, the local peoples' inventions and inversions of tradition can be understood as attempts to create a differentiated cultural space within it ... what needs to be studied ethnographically is the indigenization of modernity" (Sahlins, 1994, pp. 388-389, 390).

9. Banks and Muller, 1998, p. 415, who call the RSS "a paramilitary Hindu communal group". As a matter of fact, the action of the RSS is based on the tradition of monks who practise the martial arts.

10. Cf. Brass, 1995, p. 88: "It is mistaken to consider the BJP a 'fundamentalist' religious party". On the other hand, the handbook of Banks and Muller (of which we have made ample use) speaks of "the Hindu fundamentalist BJP" (p. 412).

11. As a matter of fact, the present study of Hindu nationalism and Islamism has been undertaken with the purpose of corroborating the view of Wallerstein.

12. Whereas mainstream Islamism is increasingly integrated in the national politics of the states concerned, the violent groups radicalize and, with the possible exception of the Palestinian ones, they also internationalize. As Zemni (1999) says, they inevitably make contact with the Afghan connection, a largely internationally structured network of war veterans from the Soviet-Afghan war. The groups and individuals who belong to this network are the product of the geopolitical interests of the United States, Pakistan and Saoudi Arabia in this area. These new forms of violence no longer have a clear ideological background. They dissolve in the structures of global capitalism, in which jihad and mafia-like business practices blend into one another.

13. Orientalism is the discourse within which, and by which, the West came to know the Orient as something ontologically and epistemologically distinct from the Occident, a merely discursive category that allowed the West to dominate the regions and peoples concerned. Orientalism was defined and exposed by Said, who himself also made the comparison of Orientalism with the recent representations of Islam (see Ashcroft and Ahluwalia, 1999). 


\section{ABSTRACTS}

In a large number of countries, fundamental shifts are taking place in the balance of power between political parties or movements. In nearly all cases, the nature of political discourse underlying national politics has changed radically, the politics of identity having now become prominent. We argue that the failure of capitalism to bring about universal prosperity is at the origin of the rise of this type of politics. It fails to secure decent living conditions for unskilled workers in the core states of Western Europe, and it fails to secure opportunities for social mobility for the equivalent of the European middle-class in the (semi)peripheral states. An analysis of three cases of politics of identity that have the connotation of civilization - Islamism, Hindu nationalism and extreme right-wing nationalism in Europe - corroborates this view. These three cases of politics of identity appear to be related to a crisis of legitimacy. However, this does not imply that Islamism and Hindu nationalism are the non-Western equivalents of extreme right-wing nationalism in Europe. The former are phenomena of the periphery, the latter is a phenomenon of the core.

In een groot aantal landen treden er in het machtsevenwicht tussen politieke partijen of bewegingen fundamentele verschuivingen op. In vrijwel alle gevallen is de aard van het politieke discours achter de nationale politiek radicaal veranderd. De identiteitspolitiek trad op de voorgrond. Aan de basis hiervan ligt naar onze mening het onvermogen van het kapitalisme zijn belofte van universele welvaart waar te maken. Het kapitalisme slaagt er niet in voor de laaggeschoolden in West-Europa volwaardige bestaansvoorwaarden te creëren. Het slaagt er ook niet in de tegenhanger van de Europese middenklasse in de (semi)perifere landen voldoende kansen op sociale mobiliteit te verschaffen. Een analyse van drie gevallen van identiteitspolitiek met de connotatie van beschaving, Islamisme, Hindoe-nationalisme en extreem-rechts nationalisme in Europa, bevestigt deze zienswijze. Bij alle drie is er een legitimiteitscrisis in het spel. Dit betekent evenwel niet dat Islamisme en Hindoe-nationalisme de niet-Westerse tegenhangers zijn van extreem-rechts nationalisme in Europa. Dit laatste is een verschijnsel van de kern, de eersten zijn verschijnselen van de periferie.

\section{INDEX}

Trefwoorden identiteitspolitiek, kapitalisme, wereld-systeem, Islamisme, Hindoe-nationalisme, extreem-rechts nationalisme in Europa

Keywords: politics of identity, capitalism, world-system, Islamism, Hindu nationalism, extreme right-wing nationalism in Europe

\section{AUTHORS}

\section{PIETER SAEY}

Department of Geography, Faculty of Sciences, Ghent University, Belgium, piet.saey@rug.ac.be

\section{MARLEEN RENDERS}

Department of the Study of the Third World, Faculty of Political and Social Sciences, Ghent University, Belgium, mrenders@hotmail.com 


\section{SIEGFRIED THIJS}

zigithijs@hotmail.com 